\title{
COMMUNICATING SOCIAL IMPACT AS A NEW TREND IN CORPORATE REPUTATION MANAGEMENT IN THE LIGHT OF CONTEMPORARY POLITICAL AND SOCIAL CHALLENGES Konrad Ciesiotkiewicz'
} (1) 
This state of affairs creates reputational threats for large companies. They are accused of an excessive and single-minded focus on profits for majority shareholders. We must recognise as important factors, affecting the potential increase of social pressures and questioning of market institutions, those periods of election campaigns and the mediatisation of social and political life variously described using concepts such as the "electronic republic" [Grossman, 1998], "media politics" [Castells, 2013, pp. 209-210], "communicative democracy" [Jakubowicz, 2004] and "electronic democracy" [Maigret, 2012, p. 446].

They are leading to a new form of democracy, handing unlimited communication tools to citizens and consumers. These tools are used to organise mass movements challenging market institutions, which can be seen in the activities of Occupy Wall Street [2019]. According to Rok [2019, p. 150] we are facing a growing wave of anger from many stakeholders in business, forcing change in the direction of making businesses' goals more social. Mediatisation creates a new space for the politicisation of many social and economic problems, thus giving them social significance, intensifying the dispute surrounding them and increasing the number of engaged actors [Duszczyk, Lesińska, Matuszczyk, 2019]. Castells [2013, p. 211] also stresses the growing role of think tanks in information policy. The primary mission of such centres is to build social awareness using various communication techniques.

One example of a global initiative presented as a reaction to the politicisation of the problem of managing large enterprises is the compact of almost 200 CEOs and owners of American companies brought together in the Business Roundtable organisation. In it they commit to apply a new paradigm, beneficial for all key stakeholders: clients, workers, suppliers, communities and the environment [Bellon, 2019]. According to the critics, the main goal guiding its creators is the need to repair their reputation, caused by the election campaign under way in the US and by attacks from politicians and voters. The Economist [2019, p. 9-10] put this subject on its cover, which attests to its importance.

One of the main motifs of the debate on corporate responsibility and communication has become the call for a turn to management based on values. Krzysztof Obłoj $[2018$, p. 165$]$ calls this a need to return to thinking that actions are taken not just based on profitability, but first of all because of duty. Terms were coined such as "values-based marketing" and "marketing 3.0", where "the raison d'etre of brands is seen in actions related to changing the world for the better" [Bakalarska, 2016, p. 47]. New approaches to CSR communication appeared, such as "CSR 2.0", in which stress is placed on companies solving social and ecological problems [Bakalarska, 2016, p. 114], as well as ever-increasing interest in alternative forms of organisation: cooperatives, social enterprises, based on a community of values and treating communications actions as sharing "the good" with their surroundings [Kociatkiewicz, Kostera, 2019].

\section{The Polish context}

According to GfK research on global trends in purchasing decisions, consumers think most about the categories values, ambitions, social affairs, relations and attitudes [Grusznic-Drobińska, 2018]. The most important conclusions related to Poland and their implications are:

- a focus on experience and not on what one owns (sensory stimulation, social and cultural capital, common experiences, growth in the popularity of the sharing economy);

- thanks to the development of information technologies, consumers have a strong conviction that they impact each other more than ever before (opinions that we trust, crowdfunding, real-time reviews, word of mouth);

- a change in behaviour towards limiting negative impact on the environment (corporate social responsibility, sensitivity to misleading information that aims to clean up reputations, so-called greenwashing). 
Poles' relationship to companies is worse than in Western countries. As many as $56 \%$ of respondents believe that people who have started their own business and achieved success deserve recognition; the figure for the European Union is $67 \%$. At the same time, Poles would like to start their own companies [Tarnawa, Węcławska, Nieć, Zbierowski, 2017]. After the outbreak of the global crisis, a significant drop in support for capitalism was noted in Poland. Between 2009 and 2014 the percentage of dissatisfied people grew from 39\% to 52\% [Grela, Konopczyński, Malko, Sobociński, 2016]. In the media and political discourse, "economic patriotism" and "consumer ethnocentrism" are proposed as antidotes to the negative consequences of globalisation [Włodarczyk, 2015]. They boil down to promoting domestic products and companies, but they're also presented as corporate responsibility for the economic and social well-being of the country where the companies operate [Wojtowicz, 2015].

\section{Companies' social impact}

There is a broad consensus on the statement that nothing harms a company's reputation more than acting in a socially irresponsible way [Gołata, 2017]. In writing about reputation, I treat it as a specific accumulation over time of images of a company [Gołata, 2012]. In addition to the time function, an important role is played by effective dialogue with stakeholders [Dąbrowski, 2010, p. 72]: Reputation "is a stable assessment, based on a coherent set of company actions and shared by various groups of stakeholders, concerning its ability and readiness to meet their expectations and provide them with a certain value." Thus, it can be assumed that reputation is what various audiences, milieus and social groups functioning in this ecosystem think and communicate about a given organisation [Grunig, 2015]. It is "shaped by a company's ability to meet stakeholders' expectations" [Dąbrowski, 2009, s. 173] and is subject to constant change.

One of the methods for building companies' reputations, particularly after the outbreak of economic crises, is the trend of CSR [Gadomska-Lila, 2012]. CSR is "companies' responsibility for their effect on society" [Ćwik, Grzybek, 2012]. It can also be said that it is "an organisation's responsibility for the effect of its decisions and actions on society and the environment, ensured by transparent and ethical behaviour, which contributes to sustainable development, including the health and welfare of society; takes into account stakeholders' expectations; complies with the law and international norms of behaviour; is integrated with the organisation's actions and practiced in its relationships" [Społeczna.... . Another important category is that of the corporate citizen (CC), accenting in a particular way an active role in social and civic life by supporting charitable, educational and cultural purposes [Nakonieczna, 2008, pp. 68-69]. Its essence is the emphasis that a company's actual obligations go far beyond its legal obligations.

Measuring and communicating social impact can be recognised as a new phenomenon that is another stage of CSR, CC or PR communications, going beyond the boundaries of mandatory financial disclosures. The traditional CSR communication model was based primarily on reporting according to Global Reporting Initiative standards [GRI...]. Communicating this impact also meets the definition of PR in Grunig's [2015] model of two-way symmetrical communication, assuming an effort at mutual understanding between the organisation and a broad range of stakeholders, and at two-way dialogue, in which the company wants to deliver value for its surroundings [Kuraszko, 2010, pp. 41-49]. Thanks to the development of online platforms and proprietary media, the role of communications services is no longer limited to representing the interests of the organisation, but also understanding and advocating for the interests and needs of the public with respect to the company of which it is a part [Grunig, 2015].

Social impact is "the consequences to human populations of any public or private actions-that alter the ways in which people live, work, play, relate to one another, organize to meet their needs and generally cope as members of society. The term also includes cultural impacts involving changes to the norms, values, and beliefs that guide and ra- 
tionalize their cognition of themselves and their society." [Burdge, Downs, Charnley, Finsterbusch, 2003].

\section{Measuring and communicating impact}

Communicating impact is based on two basic components. The first is measuring impact, where the most popular model is LGB [csr consulting, 2017]. The second component constitutes the narration surrounding data acquired by researching the impact and messages that the organisation builds around itself. To a certain degree, we can seek here an analogy to storytelling [Orzeł, 2015] in corporate communication.

Measuring impact assumes that calculations are conducted at three stages of implementation [Forum Odpowiedzialnego Biznesu, 2012]:

Stage 1. Contribution: financial, time, material support, people, areas of engagement etc.

Stage 2. Results (what has happened in the short and medium term): social (the number of people covered by the action; type of support), business, additional support received from other sources.

Stage 3. Social impact (what has changed in the long term): changes in attitudes, behaviours, knowledge, skills, the environment and many other kinds of change.

Examples of this trend may be actions taken by the Polish Chamber of Insurance (PIU) and the Polish Chamber of Information Technology and Telecommunications (PIIT), i.e. self-regulatory bodies bringing together companies from particular sectors. In 2017 the PIU published a report titled How insurance changes Poland and its people: Report on the influence of the insurance industry" [Deloitte, 2017]. In it, the organisation presents its impact in three areas: the economy and public finances; companies; and society. The PIIT, in turn, in 2016 marked the 20th anniversary of the Polish launch of GSM mobile technology by publishing a report titled Technologie mobilne w nowoczesnej Polsce - odpowiedzialny rozwój i równe szanse (Mobile technologies in today's Poland: responsible development and equal opportunities) [PwC, 2016]. The material clearly addresses the government's Strategy for Responsible Development. It argues that mobile technologies have a positive impact on the development of the economy, entrepreneurship, trade, and personal and national security. The two reports were prepared in collaboration with the advisory firms Deloitte and PwC. Below I present examples of the documents' findings.

The PIU report [Deloitte, 2017]:

Impact on the economy and public finances:

- $\quad$ The insurance industry generates almost PLN 35.9bn of added value in the Polish economy. This accounts for nearly $2 \%$ of GDP and has a significant influence on the improvement of Poland's economic well-being. For comparison, this amount is double the state budget's expenditure on higher education in 2016.

- $\quad$ The insurance industry employs 27,000 people, and additionally generates nearly 198,000 jobs in other parts of the Polish economy by paying out benefits and compensation (not including the self-employed). The industry generates the most jobs $-70,000$ - in retail, wholesale and repair of vehicles.

Impact on companies:

- $\quad$ "Employee health insurance can play a significant role in the healthcare system. Employers' attempts to improve workers' access to physicians or tests may cut the costs of sick leave by as much as $70 \%$ over the long term."

Impact on society: 
- $\quad$ "Most Poles count on a state pension and start to save too late to have a dignified standard of living in the autumn of their life. Many Poles say (40\% aged $25-45)$ that they won't live to retirement ages, which is not necessarily true, because we're living longer. Saving PLN 100 a month today, we're able to increase our standard of living after retirement by as much as $25 \%$."

The PIIT report [PwC, 2016]:

" $3.2 \%$ is the total effect of mobile technologies on the Polish economy."

"In 2015, Polish GDP grew by PLN 26.5 billion thanks to mobile telecommunications operators."

"Productivity growth thanks to the application of mobile technologies adds $1.7 \%$ to Polish GDP."

" $21.5 \%$ of the value created by the sector is reinvested. That's three times more than the figure for the economy as a whole."

"A call for help from a mobile phone reduces the likelihood of death on the scene by almost $25 \%$. That means 137 people rescued for every 100,000 patients."

\section{The example of Orange Polska}

The examples of the PIU and PIIT concern only the idea of communicating impact. A comprehensive approach means not so much sporadic activity on special occasions, but first of all a regular mechanism functioning in the organisation. A good example is the activity of Orange Polska, one of Poland's largest providers of telecommunications services, operating in all market segments [Raport..., 2018]. Research on Orange's impact is prepared in collaboration with Shipyard - the Centre for Social Innovation and Research, an NGO that acts as a think tank. In the category of social topics in the media, the company is the sector leader [Press Service Monitoring Mediów]. Measuring impact is an integral part of Orange Polska's CSR strategy. It comprises three levels of activity [Podstawy..., 2016]:

- Responsible management: company policies and procedures, including dialogue with stakeholders, an ethics committee, compliance policy, human rights and the supply chain;

- strategic areas: social and digital development, network security, environmental protection and workplace culture;

- measuring and managing social impact in six areas: local communities, employees, the economy, innovation, the environment and clients.

The data on impact are used in numerous communication channels, and they can be examined on this basis on the website [Odpowiedzialny..., 2016].

In the following analysis of key elements of Orange Polska's corporate communication, I rely on Olivier's three levels of the communications process [2010, p. 258]: the problem of meaning, the context of the group and the technical dimension, adjusted for the aspect of interpersonal relations [Kostera, 2014, p. 24]. Thus, I assume that the key elements of communication are:

- the linguistic content: what is communicated (the content of the message),

- relations: who transmits the message to whom,

- Form: the way the content is communicated.

In the case of defining the direct recipient, I take into account the assumptions of Grunig [2015] from the model of two-way symmetrical communication, in which the audience is not precisely defined. That's because this model assumes that today, various audiences access content in various ways and at various times. Thus I take into account only the key potential recipient of any message. I define them roughly on the basis of 
the form of communication (type of medium or event) and the content of the message. Example 1:

Content (message):

"The statement that every company, even the smallest, impacts its surroundings is a truism. I suspect that the larger they are, the stronger these effects. But it's difficult to define, as most companies don't measure their social impact. My guess is that this is because it's a very difficult task. We became convinced of this when we prepared our first report on Orange Polska's impact. The estimates it contained included one of our impact on Poland's GDP (5.3\% growth in 2004-2015 thanks to Internet service supplied by Orange Polska), development of local communities, growth of companies and new jobs at suppliers thanks to Orange Polska procurement. When we think about our impact, I can demonstrate it based on the agreements we signed yesterday with the Ministry of Digital Affairs. We pledged that over three years we will connect more than 4,500 schools, or almost $15 \%$ of all schools in Poland, to fibre optics. We'll pay for this out of our own funds. But for us this is a natural extension of investment in fibre - so that it will also serve the youngest Poles." [Jabczyński, 2017].

How (form of communication):

By whom, to whom (communicator/potential direct audience):

Corporate blog post. Title: "On the Impact Press spokesman/clients, employees, of Orange Polska" central and local administrations

Example 2:

Content (message):

"The nationality of capital shouldn't matter when it has a positive impact on the economic growth of the country a company is operating in. We see economic patriotism on several planes. Through investment: over the past 10 years we've engaged PLN 26 billion in infrastructure, which delivers benefits to all of society. If we wanted to build a motorway with this money, it would be about $800 \mathrm{~km}$ long. This year we've invested several hundred million złoty in fibre optics, ensuring access to very fast Internet for about 700,000 families. Over 10 years we've designated PLN 73 billion to buy products and services from Polish companies. These funds have allowed our partners to grow, and thus their partners too. The PLN 73 billion we've engaged has contributed to growth in demand for various kinds of goods and services in the amount of PLN 200 billion. We estimate that our purchases create about 40,000 jobs with our suppliers. We ourselves spend an average of PLN 2.2 billion a year on compensation, and the rest of the companies from the industry twice as much." [Wielkie znaczenie..., 2015].

\begin{tabular}{|l|l|}
\hline How (form of communication): & $\begin{array}{l}\text { By whom, to whom (communicator/poten- } \\
\text { tial direct audience): }\end{array}$ \\
\hline $\begin{array}{l}\text { Puls Biznesu daily, "The great significance } \\
\text { of large companies in the economy" }\end{array}$ & CFO/decision makers and opinion leaders \\
\hline
\end{tabular}


Example 3:

Content (message):

"World Bank economists have calculated that the more broadband Internet lines a country has, the faster its economy can grow. In Poland, the increase in the number of connections per 100 residents from $2.1 \%$ at the end of 2004 to $15.7 \%$ at the end of 2014 translated into a cumulative increase in potential GDP by $13.6 \%$. Impressive. A large proportion of the new lines are from Orange Polska (more than $36 \%$ ). These data allow us to estimate that Orange Internet connections have increased Poland's potential GDP by $4.5 \%$ during this time." [Duthoit, 2015].

How (form of communication):

By whom, to whom (communicator/potential direct audience):

Rzeczpospolita daily, "What kind of patriotism in the economy? An index of economic patriotism"

CEO/decision makers and opinion leaders

Example 4:

Content (message):

"PLN 7.8 billion of Polish GDP generated thanks to our services"

" 46,000 jobs created in other companies thanks to their work with Orange Polska" [Raport...]

How (form of communication):

By whom, to whom (communicator/potential direct audience):

Orange Polska, 2018 Integrated Report

CEO and CFO/investors, analysts, journalists, employees

Example 5:

Content (message):

"Since 2005 Orange has invested PLN 26.5 billion, an amount comparable with building four Warsaw Metro lines. During that same time, the company bought PLN 80 billion of equipment and services from Polish companies, and spent PLN 20 billion on wages and benefits for employees. The company itself employs 17,000 people, but its regular contractors employ another 40,000." [Śmietanko et al, 2017].

How (form of communication):

By whom, to whom (communicator/potential direct audience):

Debate in the Jagiellonian Club think tank:

"When a corporation wants to know what it's doing: A Stocznia, Orange and Jagiello-

Researcher, CSR employees/Experts and nian Club Debate"

\section{Example 6:}

Content (message):

"Every business has an impact on its environment. Orange Polska tries to research and measure its impact, to maximise the positive effects of the company's operations and minimise the negative ones. Where does the need to manage impact come from? What are the benefits?" [Kongres Profesjonalistów Public Relations, 2017].

How (form of communication):

By whom, to whom (communicator/potential direct audience): 
Programming block during the Professionals' Congress in Rzeszów titled Why is it worth measuring and managing a compaCSR and communications employees/PR, ny's impact on its surroundings?

\section{Example 7:}

Content (message):

"Every month we send electronic invoices to 5 million clients, which saves almost 750 tonnes of paper, or 17,000 trees. Energy use has fallen by more than $3 \%$ thanks to this Orange initiative." [Odpowiedzialny..., 2016].

How (form of communication):

By whom, to whom (communicator/potential direct audience):

Company's CSR website

Company/Clients, experts, journalists, employees

An analysis of these examples leads to four key conclusions:

1. The company proactively formulates precise messages responding to arguments raised in the public sphere by critics of the free market and the practices of many companies, including: contribution to local economic development (examples 1, 2, 4), care for the environment (7), education (1), the labour market $(4,5)$, development of smaller Polish companies $(2)$, social development $(1,2)$. Simultaneously, communication is directed to all key audiences.

2. Orange implements the model of two-way symmetrical communication (Grunig, 2015), with a clear emphasis on dialogue and engagement in the public discourse referring not only to the company's direct interests but also to the social and economic problems of the entire sector, the state and society. It attempts to interpret the concept of "economic patriotism", one of the key ideas of economic policy (Example 2 ). It discusses publicly the theme of managing and communicating social impact in Poland (6). It places itself in the role of an organisation taking responsibility for a significant part of "the common good".

3. It assigns an important role to local NGOs and think tanks as communicators. The proof of this is participation in discussions organised jointly with several such organisations (the Jagiellonian Club, Nowa Konfederacja, Stocznia) (Examples 5, 6). But what particularly distinguishes this approach is the strategic relationship with Shipyard - the Centre for Social Innovation and Research, a social organisation (outside the government and business sectors), in contrast to the earlier examples of PIU and PIIT. Both of these business associations used the services of prestigious global advisory firms. This approach is in line with the trend of the growing role for this type of organisation in communicating and building social awareness, indicated by Castells [2013].

4. It created an effective mechanism strengthening the company's media image. Analysis by Press Service Monitoring Mediów for Orange Polska [Press Service Monitoring Mediów] indicates that in the first year of communicating social impact, 1,952 publications appeared in the press, radio and television. In 2019 there were 2,593, accounting for $7.5 \%$ of all publications on the company's activities. As many as $15 \%$ of all positive reports on the company's operations result from communication of its social impact.

\section{Conclusion: potential and controversies}

In an era when people long for stories and universal narratives [Miotk, 2016, p. 158], communicating a company's social impact, showing an organisation's place in broader 
contacts, seems to have good prospects. The significant share of publications on Orange Polska based on this narrative, the way other organisations have taken it up, as shown by the examples of the insurance sector (PIU) and PIIT, indicate interest in this method of reputation building. It creates broad possibilities for conducting dialogue with key stakeholders, in particular decision makers, government and think tanks, but also grassroots social and consumer movements, customers and employees. In a time of heightened criticism of the market economy and many companies' practices, building emotional connections with a company, taking into account in management values such as "credibility, reliability, trust and responsibility" [Adamus-Matuszyńska, 2010, p. 159], becomes critically important. Communicating impact, insofar as it's connected with strategic management, and thus with systematic actions aimed at increasing positive impact and addressing shortcomings, may give a solid basis for building reputation and steering the public discourse onto a new track. I see particularly high potential in undertaking efforts to - to paraphrase Kociatkiewicz [Bauman et al, 2017, p. 21] - create an institutional culture of responsibility in deepening this current through the achievements of humanistic management. That brings in the need to understand the individual experience of employees and participants in an organisation's ecosystem, placing at the centre the experiences and fate of people in whom human dignity and development should constitute the motivation of all economic activity [Kostera, 2014]. It places great stress on active, continuous dialogue with stakeholders [Kimakowitz, 2019], moral autonomy, seeking integrity and a sense of purpose, which may be served by honest management and communication of impact [Nowa Konfederacja, 2018].

Communicating impact, because of the particular stress it places on public affairs, also creates space to re-read the idea of corporate citizenship (CC), somewhat marginalised in Poland. Companies' engagement in solving socioeconomic challenges is now strongly supported by international organisations as well, one example of which is the Sustainable Development Goals created at the initiative of the UN Secretary-General [Cele...]. More than 50 companies operating in Poland have signed them and are working with the government in this area [Nogała, 2017].

Controversies are often related to methodological difficulties in measuring impact and the lack of uniform standards [Nowa Konfederacja, 2018], the need to distinguish impact from social value [Potter, 2012] and companies' exclusive focus on positive effects, while avoiding difficult subjects [Śmietanko et al., 2017]. The argument is also made that the main aspect of communication is based to an excessive degree on longterm engagement of financial resources, and not on measuring and presenting deeper qualitative levels of impact, taking into account social and environmental costs [Bendell, 2019].

In the literature, controversy is also aroused by the very idea of corporate citizenship, or by broadening classic CSR activities to include the sphere that lies in the direct field of state authorities. The need is indicated to divide public goods, which should be supplied exclusively by public institutions [Dylus, 2014, p. 64]. On the other hand, it is pointed out that excessive engagement by companies in public affairs creates a threat that they will be incapacitated [Dylus, 2014, p. 61]. A proper assessment of the effectiveness of this trend requires precise monitoring and further interdisciplinary research in the area of CSR, CC, PR and management.

\section{References}

ADAMUS-MATUSZYŃSKA A. (2010), Współczesne wyzwania organizacji w obszarze public relations, in Majka-Rostek D. (ed.), Komunikacja społeczna a wyzwania współczesności, Difin, Warsaw.

BAKALARSKA J. (2016), Marketing wartości, Stowa i Myśli, Lublin.

BELLON M. (2019), CEO największych firm świata: interesy akcjonariuszy nie będą już dla nas priorytetem, https://businessinsider.com.pl/finanse/interesy-akcjonariuszy-nie-beda-juz-dla-nas-priorytetem-deklaruja-gi- 
ganci-biznesu/8pmlz4q [accessed: 10.01.2020].

BENDELL A. (2019), Impact investors fail to measure negative outcomes, https://www.ft.com/content/8ffb4e56-546d-11e9-8b71-f5b0066105fe [accessed: 10.01.2020].

BURDGE R.J., DOWNS M., CHARNLEY S., FINSTERBUSCH K. (2003), The Interorganizational Committee on Principles and Guidelines for Social Impact Assessment: Principles and Guidelines for Social Impact Assessment in the USA, https://www.researchgate.net/publication/242510448_The_Interorganizational_Committee_on_Principles_and_Guidelines_for_Social_Impact_Assessment_Principles_and_Guidelines_for_Social_Impact_Assessment_in_the_USA [accessed: 10.01.2020].

CASTELLS M. (2013), Władza komunikacji, Wydawnictwo Naukowe PWN, Warsaw.

Cele zrównoważonego rozwoju, https://www.un.org.pl/ [accessed: 10.01.2020].

csrconsulting (2017), Model LBG (The LBG Model), http://csrconsulting.pl/2017/02/22/lbg-poland/ [accessed: 10.01.2020].

ĆWIK N., GRZYBEK M. (2012), Analiza tematyczna Forum Odpowiedzialnego Biznesu dla Programu Partnerstwa (2015), nr 1, http://odpowiedzialnybiznes.pl/wp-content/uploads/2015/02/FOB_Analiza_tematyczna_komunikat-UE_2012.pdf [accessed: 10.01.2020].

DĄBROWSKI T. (2009), Wpływ reputacji na wartość przedsiębiorstwa i migrację kapitału, in Dobiegała-Korona B. (ed.), Migracje klientów a wartość przedsiębiorstwa, Wydawnictwa Naukowe PWN.

DĄBROWSKI T. (2010), Reputacja przedsiębiorstwa. Tworzenie kapitału zaufania, Oficyna Wolters Kluwer, Kraków.

Deloitte (2017), Jak ubezpieczenia zmieniają Polskę i Polaków. Raport o wpływie branże ubezpieczeniowej, https://piu.org.pl/wp-content/uploads/2017/12/171205_raport_wplywu_dlugi.pdf [accessed: 10.01.2020]. Abridged English version: How insurance changes Poland and its people: Report on the influence of the insurance industry https://piu.org.pl/wp-content/uploads/2017/12/PIU_report_english_version.pdf [accessed: 24.01.2020]

DEMBINSKI P. H., BERETTA S. (2014), Kryzys ekonomiczny i kryzys wartości, Wydawnictwo m, Kraków.

DUTHOIT B. (2015), Jaki patriotyzm w gospodarce? Indeks patriotyzmu ekonomicznego https://archiwum. rp.pl/artykul/1295015-Jaki-patriotyzm-w-gospodarce.html [accessed: 10.01.2020].

DUSZCZYK M., LESIŃSKA M., MATUSZCZYK K. (2019), Upolitycznienie problemu starzenia się społeczeństwa w Polsce. Teoria i praktyka, Wydawnictwa Uniwersytetu Warszawskiego, Warsaw.

DYLUS A. (2014), Przedsiębiorstwo jako obywatel (corporate citizenship). Perspektywa nauk o polityce, in Fel S. (ed.), Społeczna odpowiedzialność gospodarki. Perspektywa interdyscyplina, Wydawnictwo Katolickiego Uniwersytetu Lubelskiego, Lublin.

Forum Odpowiedzialnego Biznesu (2012), Mierzenie efektywności i wpływu społecznego działań CSR, http:// odpowiedzialnybiznes.pl/wp-content/uploads/2012/12/Mierzenie-efektywnosci-dzialan-CSR_FOB_2012.pdf [accessed: 10.01.2020].

GADOMSKA-LILA K. (2012), Społeczna odpowiedzialność biznesu w obliczu kryzysu gospodarczego, http:// www.wneiz.univ.szczecin.pl/nauka_wneiz/sip/sip28-2012/SiP-28-23.pdf [accessed: 10.01.2020].

GOŁATA K. (2012), Teoretyczne aspekty pojęcia reputacja, https://www.ue.katowice.pl/fileadmin/_migrated/ content_uploads/15_K.Golata_Teoretyczne_aspekty_pojecia_reputacja. pdf [accessed: 10.01.2020].

GRELA S., KONOPCZYŃSKI F., MALKO J., SOBOCIŃSKI M. (2016), Czy Polacy kochają wolny rynek: Ile państwa w gospodarce?, http://kalecki.org/pl/p/d/raport-3 [accessed: 10.01.2020].

GRI (Wytyczne do raportowania kwestii zrównoważonego rozwoju, ang. Global Reporting Initiative), http:// odpowiedzialnybiznes.pl/hasla-encyklopedii/gri-inaczej-wytyczne-do-raportowania-kwestii-zrownowazonego-rozwoju-ang-global-reporting-initiative/ [accessed: 10.01.2020].

GROSSMAN L.K. (1998), Republika elektroniczna, in Szczupaczyński J. (ed.), Władza i społeczeństwo, t. 2 Scholar, Warsaw.

GRUNIG J. (2015), PR Conversations: Global discussion of PR from local perspectives, http://www.prconversations.com/engaging-and-grilling-the-social-side-of-james-grunig/ [accessed: 10.01.2020].

GRUSZNIC-DROBIŃSKA D. (2018), TrendKey - globalne trendy konsumenckie. Polska na tle innych krajów, https://www.gfk.com/fileadmin/user_upload/dyna_content/PL/documents/GfK_TrendKey_Report_Oferta2018_www.pdf [accessed: 10.01.2020].

JABCZYŃSKI W. (2017), 0 wpływie Orange Polska https://biuroprasowe.orange.pl/blog/o-wplywie-orange-polska/ [accessed: 10.01.2020]. 
JAKUBOWICZ K. (2004), Demokracja komunikacyjna: (nieskończona) ewolucja pojęcia, "Studia Medioznawcze" (Media Studies), No. 3 (18).

KIMAKOWITZ E. VON (2019), About Humanistic Management, http://humanisticmanagement.network/ wp-content/uploads/2019/03/2019-HMN-Conference-About-HM.pdf [accessed: 10.01.2020].

BAUMAN Z., BAUMAN I., KOCIATKIEWICZ J., KOSTERA M., Zarządzanie w płynnej nowoczesności (2017), Fundacja Nowej Kultury Bęc Zmiana, Warsaw

KOCIATKIEWICZ J., KOSTERA M. (2019), 'Our Marketing is Our Goodness': Earnest Marketing in Dissenting Organizations, "Journal of Business Ethics", vol. 160.

Kongres Profesjonalistów Public Relations (2017), Kongres w wymiarze praktycznym - wpływ badania wpływu, https://kongresprofesjonalistow.pl/2017/01/12/kongres-w-wymiarze-praktycznym-wplyw-badania-wplywu/ [accessed: 10.01.2020].

KOSTERA M. (2014), Komunikowanie a humanistyczne aspekty roli profesjonalnej menedżera: studium etnograficzne, "Przedsiębiorczość i Zarządzanie", t. 15, nr 11, cz. 3 (Entrepreneurship and Management, vol. 15, No. 11, part 3).

KURASZKO I. (2010), Nowa komunikacja społeczna wyzwaniem odpowiedzialnego biznesu, Difin, Warsaw.

MAIGRET E. (2012), Socjologia komunikacji i mediów, Oficyna Naukowa, Warsaw.

MIOTK A. (2016), Nowy PR. Jak internet zmienił public relations (New PR: How the Internet changed public relations), Słowa i Myśli, Lublin.

NAKONIECZNA J. (2008), Społeczna odpowiedzialność przedsiębiorstw międzynarodowych, Difin, Warsaw.

NOGAŁA A. (2017), Wspólne działania na rzecz zrównoważonego rozwoju, https://raportcsr.pl/wspolne-dzialania-na-rzecz-zrownowazonego-rozwoju/ [accessed: 10.01.2020].

Nowa Konfederacja (2018), Relacja z seminarium "Mierzenie wpływu społecznego drogą do zysków i rozwoju", https://nowakonfederacja.pl/relacja-seminarium-mierzenie-wplywu-spolecznego-droga-zyskow-rozwoju/ [accessed: 10.01 .2020$]$.

OBŁ0J K. (2018), Odpowiedzialność to przyzwoitość, in Rosner A. (ed.), Rozmowy o odpowiedzialności, t. 1: Początek, nienieodpowiedzialni.pl, Warsaw.

Occupy Wall Street (2019), Facts about Occupy Wall Street, http://occupywallst.org/ [accessed: 10.01.2020].

Odpowiedzialny biznes (2016), https://www.orange.pl/kid,4004268946,id,4004268948,title,Strategia-CSR-8211-spoleczna-odpowiedzialnosc-biznesu-8211-Orange-Polska,article.html [accessed: 10.01.2020].

OLIVIER B. (2010), Nauki o komunikacji: Teoria i praktyka, Oficyna Naukowa, Warsaw.

Orange - wpływ społeczny marki w Polsce (2015), https://youtu.be/mRCs1NS9Cg8 [accessed: 10.01.2020].

ORZEt W. (2015), Storytelling, https://nowymarketing.pl/a/6715,s-storytelling-encyklopedia-marketingu [accessed: 10.01 .2020$]$.

Podstawy strategii CSR Orange Polska (2016), https://orange.binaries.pl//ocp-http/PL/Binary2/2006208/4108715847.pdf [accessed: 10.01.2020].

POTTER D. (2012), Beyond social impact to social value, https://www.theguardian.com/social-enterprise-network/2012/may/02/beyond-social-impact-social-value [accessed: 10.01.2020].

Press Service Monitoring Mediów, (2019), internal materials

PwC (2016), Technologie mobilne w nowoczesnej Polsce - odpowiedzialny rozwój i równe szanse, https://www. pwc.pl/pl/pdf/technologie-mobilne-raport-pwc.pdf [accessed: 10.01.2020].

Raport zintegrowany Orange Polska (2018), https://orange.binaries.pl/binaries/o/map/ak/html/duzefirmy/ORANGE_RAPORT_2018_final.pdf [accessed: 10.01.2020].

Rok B. (2019), Interesariusze, buntujcie się, in Mitraszewska A. (ed.), Rozmowy o odpowiedzialności, t. 3: Gniew, nienieodpowiedzialni.pl, Warsaw.

Społeczna odpowiedzialność biznesu (CSR), http://odpowiedzialnybiznes.pl/hasla-encyklopedii/spoleczna-odpowiedzialnosc-biznesu-csr/ [accessed: 10.01.2020].

ŚMIETANKO A., TRUDNOWSKI P., FILL T., HERBST J., MAZUR K., WYGNAŃSKI J., CIESIOŁKIEWICZ K. (2017), "Gdy korpo chce wiedzieć, co robi. Debata Stoczni, Orange i Klubu Jagiellońskiego", https://klubjagiellonski.pl/2017/03/08/gdy-korpo-chce-wiedziec-co-robi-debata-stoczni-orange-i-klubu-jagiellonskiego/ [accessed: 10.01.2020].

TARNAWA A., WĘCŁAWSKA D., NIEĆ M., ZBIEROWSKI P. (2017), Raport z badania Global Entrepreneurship Monitor - Polska, https://www.parp.gov.pl/storage/publications/pdf/parp_2_raport_gem_internetpl_2017.pdf [accessed: 10.01.2020]. 
"The Economist", (2019) August 24, s. 9-10.

WŁODARCZYK K. (2015), Globalizacja a patriotyzm ekonomiczny polskich konsumentów, https://www.sbc.org. pl/Content/173030/05_15.pdf [accessed: 10.01.2020].

Wielkie znaczenie dużych firm w gospodarce (2015), https://www.pb.pl/wielkie-znaczenie-duzych-firm-w-gospodarce-815982 [accessed: 10.01.2020].

WOJTOWICZ D. (2015), Dobre, bo polskie? Patriotyzm gospodarczy zyskuje popularność, https://innpoland. pl/122293,Dobre-bo-polskie-Patriotyzm-gospodarczy-zyskuje-popularnosc [accessed: 10.01.2020]. 